\title{
Phytochemical Analysis of Methanolic Extract of Mistletoe Leaf
}

\author{
Tabe, N. $\mathbf{N}^{1}$, Ushie, $\mathrm{O} \mathrm{A}^{2^{*}}$, Jones, B. B ${ }^{1}$, Kendenson, A. $\mathrm{C}^{3}$, Muktar, M. ${ }^{4}$, Ojeka, C. $\mathbf{U}^{2}$ \\ ${ }^{l}$ Department of Chemical Science, Cross River University of Technology Calabar, Nigeria \\ ${ }^{2}$ Department of Chemical Science, Federal University Wukari Nigeria \\ ${ }^{3}$ Department of Chemical Science, Federal University Kashere, Nigeria \\ ${ }^{4}$ Department of Science Laboratory Technology, Binyaminu Usman Polytechnic, Hadejia. Jigawa State, Nigeria \\ *Corresponding Author: Ushie, O A, Department of Chemical Science, Federal University, Wukari \\ Nigeria. Email: afiushie@yahoo.com
}

\begin{abstract}
The study was carried out for analysis of qualitative and quantitative analysis of phytochemicals and nutritive value of essential oils in mistletoe leaves harvested from Cross River University of Technology Calabar staff quarters. The result of the quantitative analysis shows that tannins $2.01 \pm 0.66 \mathrm{mg} / 100 \mathrm{~g}$, alkaloid $0.93 \pm 0.33 \mathrm{mg} / 100 \mathrm{~g}$, phenol $3.22 \pm 0.70 \mathrm{mg} / 100 \mathrm{~g}$, flavonoid $2.66 \pm 0.17 \mathrm{mg} / 100 \mathrm{mg}$, saponin $2.35 \pm$ $0.17 \mathrm{mg} / 100 \mathrm{~g}$. While saponin was only present in the leaves.
\end{abstract}

\section{INTRODUCTION}

Mistletoe plant is a hemi-parasitic plant that grows on trees such as cocoa, mango, guava, kola nut trees and many more is known scientifically for its nutritive content such as carbohydrate, protein, fat, fiber, energy value, and ash. This nutritive content contributes remarkably in animals and human health. Mistletoe leaves have been known for its use in the treatment of some ailments including hypertension, epilepsy, infertility, arthritis, cancer and diabetes or used as a diuretic agent (Simeon $e t$ al., 2013). The aim of this research was to determine the phytochemical constituents

\section{Materials AND Methods}

\subsection{Collection and Preparation}

The mistletoe samples used were collected from Cross River University of Technology Staff Quarters from a cocoa tree. The plant material was identified by the department of biological sciences of Cross River University of Technology (CRUTECH). The leaves were air dried under shade for two weeks. After drying, the samples were crushed to powder form using mortar and pestle. The sample in powdered form was stored in bottle till require for analysis.

\subsection{Extraction of Sample for Phytochemical Analysis}

$15 \mathrm{~g}$ of the sample was weighed into the soxhlet extractor attached to a round bottom flask containing $250 \mathrm{ml}$ of methanol and a pitch of anti-bumping granules, clamped to a retort stand attached to a heating mantle connected to a power source. The essence of adding the anti-bumping granules is to aid direct the vapour of the methanol and avoid cracking or breaking of the round bottom flask containing the methanol due to heat. The soxhlet extractor is connected a condenser with an inlet that allows the flow of water into the system and outlet that allows water flow out of the system. The inlet and outlet were connected to a water source with rubber tubing. The water flowing into the condenser aids in cooling the systems and prevents the escape of the vapour form the system as the methanol is being heated. The vapour dropped back as a result of the cooling effect of the inlet and outlet in the condenser into the round bottom flask through the reflux arm of the soxhlet extractor that was fitted with glass wool. The extraction was completed when the extract passing through the reflux arm of the soxhlet extractor into the round bottom flask was clear. The methanol was distilled and the plant extract was left in the round bottom flask. The extracted sample was used for further analyses to determine the phytochemical content 


\subsection{Qualitative Analysis of Phytochemicals}

Qualitative analysis of the crude extracts was carried out as described previously (Brain and Turner, 1975; Sofowora, 1993; Edeoga et al.; 2005; Trease and Evan, 2000; Harbone 1973; Osuagwuet al 2007) to identify the presence of secondary metabolites. The detail procedures involved in the phytochemical screening are as described by Ushie and Adamu (2010)

\subsection{Test for Alkaloids}

1.oml of the methanolic sample extract was measured into a test tube, $5.0 \mathrm{ml}$ of $2 \% \mathrm{HCl}$ was of the filtrate was treated by adding 5 drops of Wagner's reagent and shake. A reddish brown colouration added and placed on a steam bath for 10mins. It was filtered with the aid of whatman filter paper. $1.0 \mathrm{ml}$ was observed, indicating the presence of alkaloids.

\subsection{Test for Saponins}

$1.0 \mathrm{ml}$ of the methanolic sample extract was boiled with $5.0 \mathrm{ml}$ of distilled water in test tube for 5 minutes in water bath. It was decanted while still hot. The filtrate was used for the following test;

\subsection{Frothing Test}

$1.0 \mathrm{ml}$ of the filtrate was diluted with $4.0 \mathrm{ml}$ of distilled water and shaken vigorously for stable froth on standing. The stable froth was observed for 2 minutes indicating the presence of saponins.

\subsection{Test for Flavonoids}

$1.0 \mathrm{ml}$ of the methanolic sample extract was measured into a test tube, $1.0 \mathrm{ml}$ of $10 \%$ lead acetate was added and shaken for 30seconds and kept to stand. Formation of yellow precipitate was taken as a positive result for flavonoid.

\subsection{Test for Tannins}

$1 \mathrm{ml}$ of methanolic sample extract was measured into a test tube and $1 \mathrm{ml}$ of $5 \%$ bromine water was added and shaken. The formation of greenish to red precipitate was recorded as evidence for the presence of tannin.

\subsection{Test for Terpenoid}

$5 \mathrm{ml}$ of the methanolic sample extract was measured into a test tube, $2 \mathrm{ml}$ of chloroform was added, and $2 \mathrm{ml}$ of concentrated $\mathrm{H}_{2} \mathrm{SO}_{4}$ was added carefully by the side of the test tube to form a layer. No reddish brown colouration at the interface was formed, indicating absence of Terpenoid.

\subsection{Test for Phenol}

$1 \mathrm{ml}$ of the methanolic sample extract each was measure into a test tube, $1 \mathrm{ml}$ of $10 \%$ ferric chloride was added and shaken. The formation of a greenish brown colouration was taken as evidence for the phenolic.

\subsection{Quantitative Analysis of Phytochemical}

Quantitative determination of the detected secondary metabolites was carried out to know their percentages in the $S$. macrophyllaleaves by the methods described by Paviaet al., 2006, Iqbal, et al. (2011), Mudasir, (2012), Sathya (2013) and Ushieet al., 2018 with modification.

\subsection{Quantitative Analysis of Alkaloids}

$0.5 \mathrm{~g}$ of the leaves sample was dissolved in $96 \%$ ethanol, $20 \%$ tetraoxosulphate (vi) acid (1:1) $1 \mathrm{ml}$ of the filtrate was added to $5 \mathrm{ml}$ of $60 \%$ tetraoxosulphate (vi) acid and allowed to stand for $5 \mathrm{mins}$. Then $5 \mathrm{ml}$ of $0.5 \%$ formaldehyde was added and allowed to stand for $3 \mathrm{hrs}$. The reading was taken at absorbance of $565 \mathrm{~nm}$.

Calculation for $\%$ Alkaloid $=\frac{\text { Absorbance } \text { sample } \times \text { standard Concentration } \times 100 \%}{\text { Absorbance STancarde }}$

\subsection{Quantitative Analysis of Flavonoids}

The determination of flavonoids on the leaves sample was done by acid hydrolysis of spectrophotometric method. $0.5 \mathrm{~g}$ of the processed leaves sample was mixed with $5 \mathrm{ml}$ of dilute hydrochloric acid and boiled for 30mins. The boiled extract was allowed to cool and filter. $1 \mathrm{ml}$ of the 
filtrate was added to $5 \mathrm{ml}$ of ethylacetate and $5 \mathrm{ml}$ of $1 \%$ ammonium. This was then scanned from $420 \mathrm{~nm}$ and $520 \mathrm{~nm}$ for the absorbance.

Calculation for $\%$ flavonoid $=\frac{\text { Abs sample } \times \text { Std cone } \times 100 \%}{\text { Abs sample standard }}$

\subsection{Quantitative Analysis of Phenols}

The quantity of phenol is determined using spectrophotometric method. The leaves sample is boiled with $50 \mathrm{ml}$ diethyl ether or petroleum spirit. $5 \mathrm{ml}$ of the boiled sample is then pipette into $50 \mathrm{ml}$ flask and $10 \mathrm{ml}$ of distilled water is added. After the addition of the distilled water, $2 \mathrm{ml}$ of ammonium hydroxide solution and $5 \mathrm{ml}$ of concentrated pentanol is added to the mixture. The leaves sample was made up to mark and left for 30mins to react for colour development and measure at $505 \mathrm{~nm}$ wavelength using a spectrophotometric method.

Calculation for $\%$ Phenols $=\frac{\text { Absorbance sample } \times \text { Standard Concentration } \times 100 \%}{\text { Standard }}$

\subsection{Quantitative Analysis of Tannins}

The quantity of tannins isdetermined by using spectrophotometric method. $0.5 \mathrm{~g}$ of the leaves sample is weighed into plastic bottle; $50 \mathrm{ml}$ of distilled water is added and stirred for $1 \mathrm{hr}$. The sample is filtered into a $50 \mathrm{ml}$ flask and made up to mark. $5 \mathrm{ml}$ of the filtered sample is then pipette out into test tube and mixed with $2 \mathrm{ml}$ of $0.1 \mathrm{M} \mathrm{HCl}$ and $0.008 \mathrm{M} \mathrm{K}{ }_{4} \mathrm{Fe}(\mathrm{CN})_{6} .3 \mathrm{H}_{2} \mathrm{O}$. The absorbance is measured with a spectrophotometer at $395 \mathrm{~nm}$ wavelength within $10 \mathrm{mins}$.

Calculation for $\%$ Tannin $=\frac{\text { absobance of sample } \times \text { stabdard concentration } \times 100 \%}{\text { Absobance of standard }}$

\subsection{Quantitative Analysis of Saponins}

$5.0 \mathrm{~g}$ of dried sample was measured accurately with an analytical top loading balance into a thimble and was transferred into the soxhlet extractor connected to the condenser and round bottom flask of known weight, $100 \mathrm{ml}$ of methanol was used for the extraction for 3 hours to obtain the lipid and the pigment content from the sample first. After the extraction the methanol was distilled off leaving the Saponins after the evaporation the flask and the container was reweigh. The difference between the final and the initial weight of the flask represent the weight of the saponins in the sample.

Calculation for $\%$ saponins $=\frac{s-t \times 100 \%}{w}$

\subsection{Quantitative Analysis of Terpenoid}

$1.0 \mathrm{ml}$ of methanolic extract of sample was measured into test tube with a stopper, $3.0 \mathrm{ml}$ of acetic anhydride was added gently to the test tube, shaken and cooled in an ice bath for 10 minutes. The colour changed after addition of two drops of concentrated $\mathrm{H}_{2} \mathrm{SO}_{4}$ to bluish colouration. $0.1 \mathrm{mg}$ of standard terpenes tablets was weighted and extracted with $5 \mathrm{ml}$ of methanol in separating funnels. $1.0 \mathrm{ml}$ of this standard extract was measured into a test tube and treated as the above sample and the colour was allow to develop before Uv-Vis spectrophotometer measurement at a wavelength of 520 $\mathrm{nm}$ andthe result was recorded.

Calculation for $\%$ Terpenoid $=\frac{\text { Abs sample } \times \text { std } \operatorname{con} c \times 100 \%}{\text { Abs std }}$

\section{RESULT AND DISCUSSION}

\subsection{Result}

Table1. Result of Qualitative Analysis of Leaves.

\begin{tabular}{|c|c|}
\hline Phytochemical & Leaves \\
\hline Tannins & ++ \\
\hline Alkaloids & + \\
\hline Phenols & +++ \\
\hline Flavonoids & ++ \\
\hline Terpenoid & ND \\
\hline Saponins & ++ \\
\hline
\end{tabular}

Note: ND-not detected 
Table2. Result of Quantitative Analysis of Leaves

\begin{tabular}{|l|l|}
\hline Phytochemical & Leaves $\mathrm{mg} / 100 \mathrm{~g}$ \\
\hline Tannins & $2.01 \pm 0.06$ \\
\hline Alkaloids & $0.99 \pm 0.33$ \\
\hline Phenols & $3.22 \pm 0.7$ \\
\hline Flavonoids & $2.66 \pm 0.17$ \\
\hline Terpenoid & $0.00 \pm 0.00$ \\
\hline Saponins & $2.35 \pm 0.17$ \\
\hline
\end{tabular}

Note: Result is mean of triplicate of samples

\subsection{Discussion}

The result of the qualitative phytochemical analysis of mistletoe leaves are presented in table 1 . The result revealed that all the phytochemicals tested for were detected in all the samples except terpenoid.The quantitative analysis result of mistletoe leaves is reported in table 2. It shows that mistletoe leaves contains phenols $(3.22 \pm 0.07 \mathrm{mg} / 100 \mathrm{~g})$, flavonoids $(2.66 \pm 0.17 \mathrm{mg} / 100 \mathrm{~g})$, saponins $(2.35 \pm 0.17 \mathrm{mg} / 100 \mathrm{~g})$, tannin $(2.01 \pm 0.06 \mathrm{mg} / 100 \mathrm{~g})$, alkaloid $(0.93 \pm 0.33 \mathrm{mg} / 100 \mathrm{~g})$ and terpenoid (nil). Mistletoe leaves was found to contain moderate concentrations tannin, flavonoid and saponins.

The mistletoe leaf are known to carry out important medicinal roles in human body as a result of the presence of flavonoids in the hexane, chloroform and ethyl acetate extracts from the stem bark. Flavonoids have inherent ability to modify the body's reaction to allergens viruses and carcinogens. They show anti-allergic, anti-inflammatory, antimicrobial, antioxidants, Salah et al.; 1995 Okwu 2004 (Cushnie and Lamb 2005, Salah et al.; 1995 Okwu 2004).The stem bark of mistletoe leafis a very useful medicinal plant because saponins were detected. There is tremendous, commercially driven promotion of saponins as dietary supplements and nutriceuticals. It can be emphasized that mistletoe leafhas a medicinal value since it contain saponins which is useful in medicine and pharmaceutical due to its foaming ability that produce frothy effects in the food industry (George 1965). The presence of terpernoids was detected in the mistletoe leaf and hence can be used in herbal medicines (Edeogaet al.; 2005).

\section{REFERENCES}

[1] Brain, K.R and Turner (1975).The practical evaluation of phytopharmaceuticals.Bristor, john wright and sons Ltd, p84-85

[2] Cushnie, T. P. T, Lamb, A. J (2005). Antimicrobial activity of flavonoids.International Journal of Antimicrobial Agents, 26 (5): 343-356.

[3] Edeoga, H.O.; Okwu, D. E. and Mbaebie, B.O. (2005).Phytochemical Constituent of Some Nigerian plants, African Journal of Biotehnology, 4 (7), 685-688.

[4] George,A.G. (1965). Legal status and toxicity of saponins in food and cosmetics. Toxicol.,3: 85-92

[5] Harbone, J. B. (1973). Phytochemical methods, chapman and Hall, Ltd., London, p44-188

[6] Iqbal, H, Ullah, R, Rooh U, Khurram, M, Ulla, N, Baseer, A et al., (2011). Phytochemical analysis of selected medicinal plants. Afr. J. Biotech. Vol., 10: 7487-7492.

[7] MudasirA.Mir, Rajesh.T.S, Rameashkannan M.V., RiyazA.Pala and MuthuBalaji.R.A (2011). Comparative Study of Phytochemical Analysis and Antimicrobial Properties of Stigmas and Stamens of Saffron (Crocus Sativus L.) found in Kashmir. Adv Bio Tech, ,11(6): 35-38

[8] Okwu, D.E, 2004, Phytochemical, and vitamin contents of two indigenous species of South Eastern Nigeria J. Sustain Agric. Environ, 6: 30-34

[9] Osuagwu, G.G.E., Okwulehie, I.C. \&Emenike, J.O. (2007).Phytochemical and mineral content of the leaves of four Nigerian Pterocarpus 9JACQ) species.International Journal of Molecular Medicine and Advance Sciences, 3: 6-11

[10] Pavia, Donald L., Gary M. Lampman, George S. Kritz, Randall G. Engel (2006). Introduction to Organic Laboratory Techniques (4th Ed.).Thomson Brooks/Cole. pp. 797-817.

[11] Salah, W, Miller, N.J, Pagauga,G., Tijibung, Bolwel, A.P., Rice, E and Evans, C. (1995) Prlyphenolicflavonis as scavenger of aqueous phase radicals as chain breaking oxidant. Arch Biocem.Biorh, 2:339-346

[12] Sathya, V., Bharathidasan, R., Tamil, S.S., Solphia, R.N., Hakkiya, R \&Prabakaran, M. (2013). Quantitative, phytochemical analysis and in vitro antibacterial activity of Bauchiniatomatosa, L. Journal of Natural Product Resources, 3(2), 31-33. 
[13] Simeon, K. A., Illoh, H. C., Imoh, I. J. \&Imoh E. J. (2013). African mistletoe (Loranthaceae), Ethropharmacology, Chemistry and medical value: African Journal of Traditional, Complementary and Alternative Medicine. 10(4) 161-170.

[14] Sofowora, A. (1993). Medicinal plants and traditional medicines in Africa. Wiley and sons LTD, Nigeria, p223-225

[15] Trease.G.E. and Evans.W.C. (1989). Pharmacognsy, $13^{\text {th }}$ ed, BaillereTindall, London, p176-180 .

[16] Ushie.OA.andAdamu.H.M.(2010). Phytochemical Screening of Borreriaverticillata Leaves, Journal of Agriculture, Biotechnology and Ecology, 3(1):108-117

[17] Ushie O. A,Neji, P. A, Muktar, M, Ogah, E, Longbab, B.D \&Olumide.V.B (2018).

[18] Estimation of Some Phytochemicals in SwieteniamacrophyllaLeaves.Journal of Pharmaceutical Research and Reviews, 2:15

Citation: M. Shibdawa, et.al, "Physiochemical Analysis of Local (Fulani) Yoghurt Syrup Sold in Bauchi Metropolis”. International A., Journal of Advanced Research in Chemical Science (IJARCS), 5(7), pp. 7-11, DOI: http://dx.doi.org/10.20431/2349-0403.0507002

Copyright: () 2018 Authors. This is an open-access article distributed under the terms of the Creative Commons Attribution License, which permits unrestricted use, distribution, and reproduction in any medium, provided the original author and source are credited. 